\title{
Krakowskie gimnazja żeńskie przełomu XIX i XX wieku
}

\section{All-Female Secondary Schools in Krakow at the Turn of the $20^{\text {th }}$ Century}

\begin{abstract}
ABSTRAKT
Problem zapewnienia kobietom wykształcenia na poziomie średnim stał się na ziemiach polskich niezwykle istotny w drugiej połowie XIX wieku. Kwestia ta była szczególnie aktualna w zaborze austriackim, gdy w latach 90. XIX wieku dziewczęta zostały dopuszczone do egzaminów maturalnych oraz studiów uniwersyteckich. W Galicji nie istniały jednak gimnazja żeńskie, a żaden z typów ówczesnych „średnich" szkół żeńskich (takich jak wyższe szkoły wydziałowe, seminaria nauczycielskie czy licea żeńskie) nie dawał możliwości zdania egzaminu maturalnego umożliwiającego wstęp na studia wyższe. Wobec niechęci władz państwowych do tworzenia państwowych gimnazjów żeńskich równych gimnazjom męskim, jedynym rozwiqzaniem było tworzenie placówek prywatnych. Powstawały one jako odpowiedź na potrzeby społeczne i były efektem oddolnego społecznego działania. Pierwsza tego typu szkoła średnia - nie tylko na terenie Galicji, ale wszystkich trzech zaborów - powstała w 1896 roku w Krakowie. Przed wybuchem I wojny światowej funkcjonowały w Krakowie trzy klasyczne gimnazja żeńskie: I Prywatne Wyższe Gimnazjum Żeńskie, Prywatne Wyższe Gimnazjum Żeńskie im. Królowej Jadwigi oraz Prywatne Gimnazjum Żeńskie Heleny Strażyńskiej (potem: Józefa i Marii Lewickich) oraz gimnazjum realne sióstr urszulanek.
\end{abstract}

SLOWA KLUCZOWE szkolnictwo żeńskie, szkoły średnie, Galicja, matura, studia uniwersyteckie

\section{KEYWORDS}

female education, secondary schools, Galicia, secondary school exit exams, university studies

SPI Vol. 19, 2016/2

ISSN 2450-5358 e-ISSN 2450-5366 DOI: 10.12775/SPI.2016.2.004 Artykuły i rozprawy 
Koncepcja prywatnego gimnazjum żeńskiego zyskała wpierw aprobatę społecznq, a stopniowo również dużq popularność. W galicyjskich gimnazjach uczyła się ponad połowa uczennic uczęszczających do gimnazjów żeńskich położonych na terenie Przedlitawii.

\section{ABSTRACT}

The issue of providing education to women became particularly important in the Polish territories during the second half of the $19^{\text {th }}$ century. In the Austrian partition, women were allowed to take secondary school exit exams and enroll in universities in the 1890s. However, no female school at the time offered preparation to the aforementioned exams. As the government did not want to establish public all-female schools in the same way that it had created public all-male schools, a private solution was the only one. Private all-female schools emerged through a bottom-up effort as a response to the needs of society. The first school of this kind in Galicia - and all of the Polish territories - was established in Krakow in 1896. Before the outbreak of World War I, there were only four all-female secondary schools in Krakow. Still, with time, the concept of all-female secondary schools became very popular and more than half of the students of all-female secondary schools in the Habsburg Monarchy attended such schools in Galicia.

\section{Wprowadzenie}

Problem zapewnienia kobietom wykształcenia na poziomie średnim stał się na ziemiach polskich niezwykle aktualny w drugiej połowie XIX wieku. Podejście do niego było bardzo różne w poszczególnych zaborach. W zaborze pruskim dostęp taki praktycznie nie istniał, podobnie zresztą jak i dostęp do studiów wyższych. Pruskie przepisy szkolne nie regulowały sprawy kształcenia dziewcząt na poziomie średnim niemal aż do wybuchu I wojny światowej. W zaborze rosyjskim rząd pragnął przejąć kontrolę nad edukacją dziewcząt i pod koniec lat 50. XIX wieku zdecydował się na koncesje w tej dziedzinie. Polityka caratu polegała na rozbudowie rządowego szkolnictwa żeńskiego. Od 1856 roku zaczęto tworzyć w Królestwie Polskim szkoły żeńskie zbliżone programowo do szkół gimnazjalnych. Cel, 
który przyświecał tym działaniom, miał przede wszystkim charakter polityczny - chodziło o skuteczne rusyfikowanie polskich dziewcząt.

W Galicji doby autonomicznej coraz wyraźniej dawało się odczuć zainteresowanie społeczeństwa tworzeniem dla dziewcząt szkół średnich, których ukończenie zapewniałoby wstęp na studia uniwersyteckie. Niewątpliwie przyczyniła się do tego trudna na początku lat 70. XIX wieku sytuacja gospodarcza, odbijająca się na kondycji wielu rodzin i sprawiająca, że kwestia pracy zarobkowej kobiet oraz zdobywania przez nie odpowiednich kwalifikacji zawodowych stawała się coraz bardziej paląca. Jak pisze Jan Hulewicz: „Prócz przyczyn natury gospodarczej w miastach, wśród warstwy inteligenckiej, w sferach zamożnego kupiectwa, wolnych zawodów poczynała działać atmosfera liberalizmu przyjazna hasłom wyższego wykształcenia kobiet. Ale może największe znacznie przypisać by należało przenikaniu haseł i wiadomości o postępach ruchu kobiecego w Kongresówce”. Na temat edukacji kobiet w latach 70. rozwinęła się dyskusja, zwłaszcza na łamach prasy, i choć jej praktyczne efekty były wówczas znikome, to dzięki niej społeczeństwo powoli oswajało się z kwestią udostępnienia kobietom wykształcenia średniego i wyższego ${ }^{1}$.

\section{Rozwój żeńskiego szkolnictwa ponadelementarnego w Galicji}

Rozwój żeńskiego szkolnictwa ponadelementarnego, określanego też często mianem „średniego”, w Galicji w dobie autonomicznej miał przebieg dość skomplikowany. Spowodowane to było w dużej mierze postawą władz oświatowych, zarówno austriackich, jak i krajowych. Władze oświatowe szukały bowiem rozwiązań połowicznych, zmierzających do podnoszenia poziomu szkół, bez zmiany faktycznego celu ich kształcenia. Ciągle bardzo wyraźnie podkreślano odrębność cech fizycznych i psychicznych dziewcząt oraz czekających je w przyszłości zadań społecznych, a co za tym idzie, tworzenia odrębnych typów szkół przeznaczonych dla dziewcząt. Ta postawa władz była niezwykle trwała, choć zdawano sobie coraz wyraźniej

1 J. Hulewicz, Sprawa wyższego wyksztatcenia kobiet w Polsce w wieku XIX, Kraków 1939, s. 243. Patrz więcej o tej dyskusji: tamże, s. 243-258, też A. Bilewicz, Prywatne, średnie, ogólnoksztatcace szkolnictwo żeńskie w Galicji w latach 1867-1914, Wrocław 1997. 
sprawę, że proponowane rozwiązania nie zaspokajają rzeczywistych potrzeb kobiet ${ }^{2}$.

Zresztą i sam termin „szkoła średnia” w odniesieniu do ówczesnego szkolnictwa żeńskiego nie był precyzyjny. Stosowano go na określenie wszystkich szkół ponadelementarnych, które powstawały w Austrii w ostatnim ćwierćwieczu wieku XIX. Nazywano je też niekiedy „wyższymi”, ponieważ zajmowały szczebel wyższy w stosunku do szkolnictwa ludowego ${ }^{3}$.

Najwcześniej powstały żeńskie seminaria nauczycielskie, jako szkoły ponadelementarne o charakterze zawodowym. W schemacie szkolnictwa rządowego mieściły się także żeńskie szkoły wydziałowe, stanowiące typ szkół ludowych wyższego szczebla, zakładanych w miastach, wreszcie od 1900 roku zaczęly powstawać popierane przez ministerstwo licea. Nauka w liceach kończyła się egzaminem maturalnym, który nie dawał jednak wstępu na studia uniwersyteckie. Wszystkie te szkoły nie stanowily odpowiednika gimnazjum męskiego, które rzeczywiście było stopniem pośrednim pomiędzy szkołą ludową a szkołą wyższą. Takim odpowiednikiem mogło stać się jedynie gimnazjum żeńskie. Zanim jednak ukształtowało się ono jako ośmioklasowy zakład ogólnokształcący i w pełni dostosowało do wzorów gimnazjum męskiego, musiało przejść wieloletnią ewolucję 4 .

Sprawa dostępu kobiet do uniwersytetów pojawiła się po raz pierwszy w Austrii w rozporządzeniu ministerialnym z 1878 roku na fali otwierania dla kobiet uniwersytetów zachodnich. Stanowisko rządu austriackiego było jednoznaczne - kobiety mogą być dopuszczane do studiów wyższych wyjątkowo, jedynie jako hospitantki i za zgodą władz uczelni oraz ministerstwa. Mogły też przystępować do egzaminu maturalnego w wyznaczonych gimnazjach męskich jako eksternistki, jednak otrzymane przez nie świadectwo nie uprawniało do podejmowania studiów uniwersyteckich ${ }^{5}$.

W Galicji, podobnie jak i w całej monarchii austro-węgierskiej, zgodnie z rozporządzeniem ministerstwa z 9 marca 1896 roku usta-

2 R. Dutkowa, Żeńskie gimnazja Krakowa w procesie emancypacji kobiet (18961918), Kraków 1995, s. 7.

3 Tamże, s. 9.

4 Tamże, s. 7, 20.

5 Tamże, s. 20-21. 
lono szczegółowo warunki przystępowania dziewcząt jako eksternistek do matury w gimnazjach męskich. Dziewczęta mogły zdawać egzamin dojrzałości w gimnazjach męskich ${ }^{6}$ za zezwoleniem Rady Szkolnej Krajowej, jeżeli ukończyły 18 rok życia, przedłożyły świadectwo z ostatniej klasy gimnazjalnej lub odbytej nauki prywatnej w zakresie programu gimnazjum klasycznego. Zaznaczano jednak, że zarządzenie odnosi się jedynie do wąskiego grona kobiet (np. niezamężnych, zmuszonych zarabiać na siebie), zaś ministerstwo nie zamierza wspierać na szerszą skalę zakładania szkół średnich dla dziewcząt. Faktycznie jednak uchylono kobietom furtkę, czego wyrazem było wpierw zwiększenie się liczby matur eksternistycznych, a w dalszej kolejności prywatnych gimnazjów żeńskich.

W rok później, na mocy rozporządzenia z dnia 23 marca, dopuszczono kobiety z obywatelstwem austriackim do studiów na wydziałach filozoficznych uniwersytetów galicyjskich jako słuchaczki zwyczajne, a 24 marca tego samego roku maturzystkom gimnazjalnym przyznano prawo do studiowania.

Wszystkie wspomniane decyzje władz oświatowych nie były jednak wyrazem zmiany ich stanowiska w kwestii wyższego i średniego kształcenia kobiet. Ciągle bowiem podkreślano odmienność ról życiowych kobiet i mężczyzn, kładąc nacisk na spełnianie przez nie ról matek i żon. Ostrożność władz podyktowana była głównie strachem przed nadprodukcją inteligencji, powiększoną przez ewentualną konkurencję na rynku pracy ze strony kobiet. Państwo konsekwentnie zatem sprzeciwiało się tworzeniu rządowych szkół średnich żeńskich typu gimnazjum męskiego. Aż do końca istnienia monarchii habsburskiej nie utworzono, ani też nie upaństwowiono ani jednego żeńskiego gimnazjum ${ }^{7}$.

6 Wyznaczono cztery gimnazja w Galicji, w których dziewczęta mogły składać egzamin dojrzałości - w języku polskim w Gimnazjum św. Anny w Krakowie i Gimnazjum im. Franciszka Józefa we Lwowie, w języku niemieckim w II Gimnazjum we Lwowie, a w języku rosyjskim w Gimnazjum Akademickim we Lwowie.

7 R. Dutkowa, Żensskie gimnazja Krakowa w procesie emancypacji kobiet (18961918), s. 23-24. Por.: B. Czajecka, „Z domu w szeroki świat...”. Droga kobiet do niezależności w zaborze austriackim w latach 1890-1914, Kraków 1990, s. 108-109; A. Bilewicz, Prywatne, średnie, ogólnoksztatcace szkolnictwo żenskie w Galicji w latach 1867-1914, dz. cyt., s. 31-33. 
Nie istniały również średnie szkoły koedukacyjne. W 1910 roku na mocy rozporządzenia Ministerstwa Oświaty dziewczęta zostały dopuszczone w charakterze hospitantek do męskich gimnazjów, jednak było to zjawisko o charakterze ograniczonym. Po pierwsze istniał limit - dziewczęta nie mogły stanowić więcej niż wpierw 5, a następnie $10 \%$ wszystkich uczniów, a po drugie, w rzeczywistości zjawisko to dotyczyło głównie małych miejscowości ${ }^{8}$.

Jedynym rozwiązaniem było zakładanie szkół prywatnych, co oczywiście miało ten mankament, iż pozwalało uczyć się w nich tylko dziewczętom pochodzącym $\mathrm{z}$ rodzin, które stać było na zapłacenie czesnego.

Sprawę zakładania prywatnych szkół normowała ustawa państwowa z dnia 14 maja 1869 roku. Zgodnie z nią, szkoły prywatne mogły działać jedynie pod nadzorem władz państwowych i za zgodą Rady Szkolnej Krajowej, jednak otworzyć szkołę mógł każdy, kto był w stanie zabezpieczyć jej funkcjonowanie pod względem finansowym i naukowo-dydaktycznym. Niektóre z nich, pod określonymi warunkami, mogły otrzymać od ministerstwa uprawnienia szkół państwowych ${ }^{9}$. Dzięki liberalnemu charakterowi zawartych w ustawie przepisów nastąpił rozwój średniego szkolnictwa żeńskiego i zostały otwarte m.in. gimnazja żeńskie ${ }^{10}$.

\section{Utworzenie pierwszego na ziemiach polskich gimnazjum żeńskiego w Krakowie}

Pierwsze na ziemiach polskich gimnazjum żeńskie powstało w Krakowie, a inicjatorką jego założenia była Kazimiera Bujwidowa. Wykorzystała ona istniejące w Szwajcarii od 1887 roku Stowarzy-

8 T. Męczkowska, Szkoty mieszane. Koedukacja, Warszawa 1920, s. 49-50. Por. A. Bilewicz, Prywatne, średnie, ogólnoksztatcqce szkolnictwo żenskie w Galicji w latach 1867-1914, dz. cyt., s. 34-35.

9 Warunki te dotyczyły przestrzegania regulaminu szkolnego, rozporządzeń władz szkolnych w zakresie używania zatwierdzonych oficjalnie podręczników i realizowania pełnego programu nauczania obowiązującego w szkołach państwowych.

10 M. Stinia, Rola spoteczeństwa galicyjskiego jako organizatora średniego szkolnictwa prywatnego wo okresie autonomii, w: $Z$ dziejów polskiej kultury $i$ oświaty od średniowiecza do poczq̨tków XX wieku, red. K. Jakubiak, T. Maliszewski, Kraków 2010, s. 134. 
szenie Pomocy Naukowej dla Polek im. J.I. Kraszewskiego, którego jednym z celów było założenie szkoły średniej dla dziewcząt pragnących rozpocząć studia wyższe. Stowarzyszenie nie działało zbyt prężnie, głównie ze względu na problemy finansowe. Jednak gdy w listopadzie 1895 roku do Stowarzyszenia przystąpili Kazimiera i Odo Bujwidowie, jego działalność się ożywiła. Powołano sekcję ds. założenia szkoły, której przewodniczyła Bujwidowa. Sekcja miała za zadanie przygotować projekt przyszłej szkoły.W dniu 11 marca 1896 roku sekcja przekształciła się w Towarzystwo Szkoły Gimnazjalnej Żeńskiej (dalej w skrócie: TSGŻ). Wybrano Zarząd, któremu przewodniczył Napoleon Cybulski, jego zastępcą został Bronisław Trzaskowski, sekretarzem Maria Turzyma-Wiśniewska, a skarbnikiem Odo Bujwid. Towarzystwo miało stać się w przyszłości wyłącznym właścicielem i opiekunem szkoły. Jako osoby upoważnione do podejmowania wszelkich działań w sprawach formalnych dotyczących szkoły wybrano dwóch profesorów Uniwersytetu Jagiellońskiego, Odona Bujwida i Napoleona Cybulskiego, oraz zasłużonego pedagoga Bronisława Trzaskowskiego ${ }^{11}$.

TSGŻ wykazało się niezwykłą prężnością i przezwyciężając ogrom trudności materialnych, organizacyjnych i personalnych, zdołało doprowadzić do otwarcia „prywatnej szkoły żeńskiej z programem gimnazjalnym" ${ }^{\prime 2}$. Była to pierwsza tego typu szkoła na ziemiach polskich, a trzecia - po Pradze (1891) i Wiedniu (1893) - w monarchii austro-węgierskiej.

Zgodę na założenie szkoły wyraziła Rada Szkolna Krajowa w dniu 26 czerwca 1896 roku. Oficjalna nazwa brzmiała „szkoła gimnazjalna”. Odmówiono jej nazwy „gimnazjum” ze względów na obowiązujące przepisy finansowe ${ }^{13}$, a ponadto - jak pisał Józef Zachara, późniejszy dyrektor gimnazjum - „Ówczesne władze szkolne obawiały się bowiem, aby z gimnazjami żeńskimi nie było w przyszło-

11 Sprawozdanie Towarzystwa szkoty gimnazjalnej żenskiejza rokszk. 1899/1900, Kraków 1900, s. 4. Patrz więcej: K. Dormus, Kazimiera Bujwidowa 18671932. Życie i dziatalność spoteczno-oświatowa, Kraków 2002, s. 72-75.

12 Sprawozdanie Towarzystwa szkoty gimnazjalnej żeńskiej za rok szk. 1900/01, Kraków 1901, s. 6.

13 Założyciele, zgodnie $\mathrm{z}$ wymogami, powinni dysponować funduszem w wysokości 80000 florenów, tymczasem fundusz ten wynosił tylko 10000 florenów i to głównie w postaci skryptów dłużnych. 
ści zbyt wiele kłopotów, odnoszono się do nich niechętnie, a nawet przyjęto dla tych szkół skromniejszą nazwę «szkoły gimnazjalne»"14.

Uroczyste otwarcie szkoły nastąpiło w dniu 4 września 1896 roku. Pierwszą siedzibą szkoły była kamienica przy ul. św. Jana 11. Od roku szkolnego 1904/05 szkoła osiadła we własnym budynku przy ul. Wolskiej 13 (dziś ul. Piłsudskiego) ${ }^{15}$.

Za wzór przyjęto funkcjonujące już od kilku lat szkoły gimnazjalne żeńskie w Pradze i Wiedniu. Podobnie jak one, szkoła krakowska miała być 6-letnia. Cztery wyższe klasy miały odpowiadać programowi wyższego gimnazjum męskiego, a dwie niższe uzupełniać wiadomości uczennic do poziomu męskiego gimnazjum niższego. Do szkoły przyjmowano dziewczęta, które ukończyły 14 lat, były absolwentkami 4-klasowej szkoły wydziałowej lub złożyły stosowny egzamin wstępny. Początkowo uruchomiono tylko jeden kurs - klasę I. Dopiero po 17 latach, w roku 1912/13, szkoła miała osiem klas gimnazjalnych, osiągając stopień organizacyjny w pełni odpowiadający męskim gimnazjom klasycznym ${ }^{16}$.

W momencie rozpoczynania działalności szkoła liczyła 26 uczennic, ale w ciągu następnego dziesięciolecia liczba ta zwiększyła się dziesięciokrotnie. Szkoła cieszyła się znakomitą opinią oraz dużym powodzeniem. Licznie przybywały dziewczęta spoza Galicji, wśród których najwięcej było królewianek ${ }^{17}$.

W 1900 roku miał miejsce pierwszy egzamin maturalny, który odbył się w Gimnazjum św. Anny, ponieważ szkoła nie miała jeszcze praw publicznych. Dziewczęta mogły zdawać maturę w swojej szkole dopiero od czerwca 1908 roku, gdy gimnazjum uzyskało prawa publiczne. Otrzymało je dla czterech wyższych klas w grudniu $1907 \mathrm{roku}^{18}$.

J. Zachara, Historia pierwszego na ziemiach Polski Gimnazjum Żeńskiego im. E. Plater w Krakowie. (Przemówienie na uroczystości czterdziestolecia), Kraków 1937, s. 3, 5.

15 Tamże, s. 4, 6.

16 Tamże, s. 5-6; R. Dutkowa, Żeńskie gimnazja Krakowa w procesie emancypacji kobiet (1896-1918), dz. cyt., s. 29-30.

17 K. Dormus, Kazimiera Bujwidowa 1867-1932, dz. cyt., s. 77.

18 J. Zachara, Historia pierwszego na ziemiach Polski Gimnazjum Żeńskiego im. E. Plater w Krakowie, dz. cyt., s. 8-9, 15. 
Mimo tych sukcesów, sytuacja w szkole była trudna. Składały się na nią dwa czynniki: problemy finansowe oraz konflikty wewnętrzne, które przeniosły się na szerszą arenę. Sytuacja materialna szkoły była trudna. Gimnazjum co prawda otrzymywało pewne subwencje od Rady Miasta Krakowa i sejmu krajowego (Ministerstwo Oświaty konsekwentnie odmawiało pomocy finansowej), jednak faktycznie utrzymywało się ono ze składek członków TSGŻ oraz opłat uczennic ${ }^{19}$.

$\mathrm{Na}$ losach szkoły zaważyły jednak w zdecydowanie bardziej istotny sposób konflikty wewnętrzne: nieporozumienia wewnątrz TSGŻ, przenoszące się na płaszczyznę stosunków pomiędzy Towarzystwem a szkoła, oraz spory wewnątrz grona nauczycielskiego.

Źródłem nieporozumień wewnątrz TSGŻ były różnice zdań pomiędzy grupą konserwatywną (tzw. „klerykałowie”), na czele której stał dyrektor Bronisław Trzaskowski, a odłamem radykalnym (tzw. „liberałowie”), grupującym się głównie wokół Bujwidów. Różnice zdań dotyczyły sposobu prowadzenia szkoły i jej charakteru. Spory te miały charakter światopoglądowy, odnoszący się do kwestii podejścia do problemów politycznych, narodowych, religijno-etycznych, ale dotyczyły też kwestii administracyjnych i własnościowo-finansowych. Nakładały się na to problemy ambicjonalne, zwłaszcza ze strony dyrektora Trzaskowskiego, który z czasem zaczął uznawać się za jedynego prawowitego właściciela szkoły. W maju 1903 roku dyrektor Trzaskowski po długiej i burzliwej dyskusji na posiedzeniu TSGŻ oświadczył, że jedynymi prawowitymi właścicielami szkoły są osoby, które bezpośrednio uzyskały zgodę Rady Szkolnej Krajowej na jej prowadzenie, tj. on sam oraz profesorowie Bujwid i Cybulski. Bujwid i Cybulski nie podzielali tego zdania. Oświadczenie stało się zarzewiem sporów i walk o kompetencje. Ostatecznie dopiero w roku 1906 Namiestnictwo uznało, że całe TSGŻ jest właścicielem szkoły, a Bujwid, Cybulski i Trzaskowski tylko jego mandatariuszmi ${ }^{20}$.

Uwagę mieszkańców Krakowa przyciągały spory wewnątrz grona nauczycielskiego. Bohaterkami głośnego skandalu rozgrywającego się w szkole, w kilku odsłonach na przestrzeni lat 1903-1908,

19 K. Dormus, Kazimiera Bujwidowa 1867-1932, dz. cyt., s. 80-81.

20 J. Zachara, Historia pierwszego na ziemiach Polski Gimnazjum Żeńskiego im. E. Plater w Krakowie, dz. cyt., s.10, 14. Zob. też $W$ sprawie prywatnej średniej szkoty żenskiej w Krakowie. Odpowiedź Zarzqdu Towarzystwa szkoty gimnazjalnej żeńskiej na dwa artykuty „Czasu”, Kraków 1905. 
były pracujące tam nauczycielki: Stefania Sempołowska i Marcelina Kulikowska ${ }^{21}$.

W szkole uczyło w tym czasie pięć kobiet: Helena Witkowska (historia i geografia), Maria Kraskowska (matematyka), Marcelina Kulikowska (zoologia), Zofia Baraniecka (język francuski), Ewelina Wróblewska (matematyka) i Stefania Sempołowska (geografia). Ponadto w szkole zatrudniona była jako ochmistrzyni Pelagia Dąbrowska, wdowa po Jarosławie. Witkowska, Kulikowska i Wróblewska były absolwentkami zachodnich uniwersytetów: francuskich lub szwajcarskich. Witkowska, Kulikowska, Wróblewska i Sempołowska były królewiankami, osiadłymi w Krakowie z wyboru lub konieczności. Wszystkie one należały do „bojowego” pokolenia nauczycielek szkół średnich, głęboko zaangażowanych w sprawy oświaty, problematykę społeczną i narodową, sympatyzujących z hasłami emancypacji kobiet, wyznających radykalne - jak na warunki galicyjskie poglądy ${ }^{22}$.

Stefania Sempołowska rozpoczęła pracę w szkole we wrześniu 1903 roku po wydaleniu jej z Królestwa Polskiego. Zatrudniono ją jako nauczycielkę geografii, chcąc pomóc jej w bardzo trudnej sytuacji materialnej. Jej zachowanie już w chwili rozpoczęcia przez nią pracy stało się przyczyną dwóch głośnych wydarzeń. Pierwszy incydent dotyczył sporu wokół wyboru obchodzonych w szkole uroczystości, gdy Sempołowska skrytykowała decyzję o uczczeniu imienin cesarzowej ${ }^{23}$. Drugi incydent Sempołowska wywołała w sposób, jak się wydaje, niezamierzony. Chodziło mianowicie o nieodmówienie przez Sempołowską modlitwy z uczennicami przed lekcją. Sempołowska uczyła wcześniej w Warszawie, gdzie obowiązywały inne zwyczaje, polegające na tym, iż modlitwę z dziewczynkami odmawiała dama klasowa, już po wyjściu nauczyciela z sali. Wiadomość o zachowaniu się nowej nauczycielki przedostała się do szerszej wia-

21 Patrz więcej: K. Dormus, Poetka i nauczycielka - Marcelina Kulikowska (1872-1910), „Rozprawy z Dziejów Oświaty” 2011, t. 48, s. 47-65.

22 Sprawozdanie Dyrektora prywatnej średniej szkoty żeńskiej z programem gimnazjalnym w Krakowie za rok szkolny 1902/03, Kraków 1903, s. 27; K. Dormus, Poetka i nauczycielka - Marcelina Kulikowska (1872-1910), dz. cyt., s. $50-51$.

23 S. Sempołowska, Niedola mtodzieży w szkole galicyjskiej. Kilka stów o narodowej szkole w Galicji, Kraków 1906, s. 19. 
domości i wywołała wzburzenie, zaś dyrektor Trzaskowski zdymisjonował ją bez jakiegokolwiek osobistego $\mathrm{z}$ nią porozumienia się ${ }^{24}$. Konflikt udało się szybko zażegnać dzięki inspektorowi szkolnemu dr. Ludomiłowi Germanowi. Zwolnioną chwilowo Sempołowską przywrócono z zastrzeżeniem, że nie będzie prowadziła pierwszych ani ostatnich lekcji ${ }^{25}$.

Atmosfera w szkole uspokoiła się aż do konferencji nauczycielskiej we wrześniu 1904 roku, na której dyrektor Trzaskowski zwrócił się do nauczycielek - Kulikowskiej oraz jej dwóch koleżanek (prawdopodobnie Witkowskiej i Wróblewskiej) z prośbą, by wzięły na siebie obowiązek uczęszczania $\mathrm{z}$ uczennicami na niedzielne nabożeństwa. „Odmówiłam - pisała o tym wydarzeniu Kulikowska - motywując tym, że innowację chodzenia dziewcząt do kościoła uważam za niepotrzebną, gdyż daleko właściwszym jest, gdy każda z matką własną, jak bywało dotychczas, na nabożeństwo świąteczne pójdzie”. Dyrektor w odpowiedzi na odmowę oświadczył, że sprzeciwiające się nauczycielki muszą się podać do dymisji ${ }^{26}$. Ponownie za nauczycielkami wstawił się inspektor szkolny Ludomił German, stwierdzając, że wypełnianie obowiązków religijnych, zgodnie z przepisami, obowiązuje jedynie nauczycieli rządowych ${ }^{27}$.

Wewnątrz szkoły jednak, jak pisze Józef Zachara, gromadziło się „coraz więcej palnego materiału”. Nieporozumienia wśród grona („ciche a trwające"), wspomniana już walka o wpływy (a co za tym idzie, o prawo własności szkoły i płynące $z$ tego tytułu dochody) między Zarządem TSGŻ a dyrektorem Trzaskowskim, nasilająca się ponownie wiosną 1905 roku, wreszcie spór pomiędzy „liberałami” a „klerykałami” "o zasady czy idee, jakimi kierować się należy w wychowaniu młodzieży" były przyczyną kolejnych burzliwych wydarzeń, którym z ogromnym zainteresowaniem przyglądali się krakowianie. Niebagatelną rolę w rozwoju wydarzeń odegrał krakowski „Czas”. W kwietniu 1905 roku (nr 80 i 82) opublikował dwa artykuły $W$ gimnazjum żeńskim oraz $Z$ gimnazjum żeńskiego, w których oskarżano

Sprawa gimnazjum żeńskiego, Biblioteka Jagiellońska, rkps 7388 II, k. 45-46. J. Zachara, Historia pierwszego na ziemiach Polski Gimnazjum Żeńskiego im. E. Plater w Krakowie, dz. cyt., s. 11.

Sprawa gimnazjum żeńskiego, Biblioteka Jagiellońska, rkps 7388 II, k. 33-34. Tamże, k. 35, 37. 
TSGŻ o postawę „nienarodową i niechrześcijańską”, czego wyrazem miało być m.in. zatrudnienie z szkole jako nauczycielek „dwóch pań, które kończyły studia w Genewie”.

W ślad za artykułami „Czasu” posypała się cała lawina utrzymanych w podobnym tonie tekstów. Na terenie szkoły doszło tymczasem do zmian personalnych. Ustąpił dyrektor Trzaskowski, a jego miejsce (tymczasowo) zajął Tomasz Sołtysik, były dyrektor III Gimnazjum im. Sobieskiego w Krakowie. Trzaskowski, mimo odejścia ze stanowiska, nie przestał oddziaływać na sytuację w szkole. Przy poparciu władz oraz większości nauczycieli przeprowadził secesję, w wyniku której powstało w Krakowie drugie żeńskie gimnazjum im. Królowej Jadwigi, prowadzone w duchu narodowo-katolickim ${ }^{28}$.

Wszystko to skomplikowało znacznie sytuację pierwszego gimnazjum. Wraz z Trzaskowskim odeszła bowiem znakomita część grona pedagogicznego i trzeba było organizować je od nowa. Odeszła też duża grupa uczennic, zwłaszcza katoliczek. Liczba uczennic pierwszego gimnazjum spadła z 215 do $136 . Z$ mienił się też ich skład wyznaniowy, bo o ile poprzednio uczennice wyznania mojżeszowego stanowiły $1 / 3$ wszystkich uczących się w pierwszym gimnazjum, to teraz było ich ponad $3 / 4^{29}$.

Pogorszyła się również znacznie sytuacja finansowa pierwszego gimnazjum, ponieważ sejm odebrał swoją subwencję, przekazując ją nowo powstałej szkole, zaś Rada Miasta podzieliła swoją pomiędzy obie szkoły ${ }^{30}$.

Równocześnie w sprawę zaangażowali się politycy. Punkt kulminacyjny nastąpił w październiku 1905 roku, gdy na arenie sejmu krajowego doszło do dyskusji nad sprawozdaniem komisji szkolnej sporządzonym w oparciu o relację Rady Szkolnej Krajowej, dotyczącej szkolnictwa średniego w Galicji. Sprawa szkoły gimnazjalnej żeńskiej wywołała wówczas sporo emocji. $\mathrm{Na}$ posiedzeniu plenarnym w dniu 27 października zabrał głos m.in. Stanisław hrabia Tarnowski jako referent komisji szkolnej. Mówił on m.in. o niedobrym stanie moralnym

J. Zachara, Historia pierwszego na ziemiach Polski Gimnazjum Żeńskiego im. E. Plater w Krakowie, dz. cyt., s. 12-14.

29 Sprawozdanie Dyrektora prywatnej średniej szkoty żeńskiej z programem gimnazjalnym w Krakowie za rok szkolny 1905/06, Kraków 1906, s. 47.

30 W. Najdus, Szkice z historii Galicji, t. 2: Galicja w latach 1905-07, Warszawa 1960, s. 468-469. 
uczniów galicyjskich szkół średnich, o zdobywających wśród nich coraz większą popularność szkodliwych prądach. „[...] nie brak przykładów i dowodów na ostateczny cel tych prądów, którym jest odchrześcijanienie społeczeństwa" - stwierdzał, przywołując jako przykład sytuację panującą w pierwszym żeńskim gimnazjum krakowskim ${ }^{31}$.

Dyskusja w sejmie miała swe dalsze reperkusje. Książęco-biskupi konsystorz diecezji krakowskiej odmówił bowiem przyznania szkole katechety na rok szkolny 1905/06. Była to sprawa ważna, albowiem zgodnie z przepisami szkoła, w której nie nauczano religii, nie mogła być traktowana jako pełnowartościowa szkoła średnia, a tym bardziej uzyskać praw szkoły publicznej. Rada Szkolna Krajowa zwracała dyrekcji szkoły uwagę, że bez oficjalnego nauczyciela religii rzymskokatolickiej zakład nie może zachować charakteru szkoły średniej, a Rada Szkolna Krajowa „musiałaby ją [szkołę] uważać jako niezorganizowane kursa”. Przez dwa i pół roku zarówno TSGŻ, jak i dyrekcja starały się o zmianę tej decyzji. Kardynał Jan Puzyna pozostawał jednak nieugięty. W tej trudnej sytuacji dziewczęta zdawały egzaminy z religii na zewnątrz, a dopiero w marcu 1908 roku zgodę na nauczanie religii uzyskał ksiądz Józef Kondolewicz ${ }^{32}$.

Konflikty i skandale związane z pierwszym gimnazjum żeńskim nie tylko wpłynęły na sytuację wewnętrzną szkoły, ale stały się katalizatorem przyspieszającym zakładanie kolejnych tego typu szkół w Krakowie.

\section{Krakowskie gimnazja żeńskie w latach 1905-1914}

Jako pierwsza powstała „średnia szkoła żeńska z charakterem gimnazjalnym” im. Królowej Jadwigi. Inicjatorami jej założenia byli dyrektor Trzaskowski oraz część grona nauczycielskiego, która odeszła z pierwszego gimnazjum żeńskiego.

31 Dyskusja o szkotach średnich w tegorocznej sesji sejmowej, „Muzeum” 1905, s. 983. Patrz też: J. Hulewicz, Udziat Galicji w walce o szkote polskq 18991914, Warszawa 1934, s. 72.

32 Sprawozdanie Towarzystwa szkoty gimnazjalnej żeńskiej za czas od kwietnia 1905 r. do 21 grudnia 1905 r., Kraków 1905, s. 8-11; J. Zachara, Historia pierwszego na ziemiach Polski Gimnazjum Żeńskiego im. E. Plater w Krakowie, dz. cyt., s. 15. 
W dniu 12 czerwca 1905 roku Rada Szkolna Krajowa udzieliła dwóm profesorom Uniwersytetu Jagiellońskiego, Tadeuszowi Browiczowi i Józefowi Tretiakowi, oraz emerytowanemu profesorowi gimnazjalnemu Janowi Czubkowi koncesję na otwarcie średniej szkoły żeńskiej o charakterze gimnazjum męskiego. Szkoła miała być prowadzona w duchu narodowym i religijnym. Dyrektorem szkoły został Wiktor Schmid, dotychczasowy profesor III Gimnazjum Męskiego im. Jana Sobieskiego w Krakowie. Gimnazjum mieściło się w Pałacu Spiskim.

W sierpniu 1905 roku rozpoczęto zapisy. Od razu zapisało się 138 uczennic, w tym 92 uczennice, które przeszły z pierwszego gimnazjum. Do nowej szkoły przeszły wyłącznie katoliczki, jednak grupa uczennic wyznania mojżeszowego i w tej szkole była duża, utrzymując się w kolejnych latach na poziomie 30-40\%.

Nowo powstałe gimnazjum początkowo było 6-letnie, składające się z klas V-VIII oraz dwóch kursów przygotowawczych. Jednak już w roku szkolnym 1909/10 szkoła stała się szkołą 8-klasową, równą gimnazjum męskiemu. Wcześniej jeszcze, i to bardzo szybko jak na ówczesne warunki, bo już 23 stycznia 1906 roku, szkoła uzyskała „prawo publiczności”. Wpłynął na to niewątpliwie fakt, iż szkoła zaczynała swoją działalność od razu jako placówka wysoko zorganizowana, mając wsparcie Rady Szkolnej Krajowej, sejmu krajowego oraz Rady Miasta Krakowa ${ }^{33}$.

Pierwsze gimnazjum zapewniło powstanie też i trzeciemu w Krakowie gimnazjum żeńskiemu Heleny Strażyńskiej. W 1902 roku Strażyńska przejęła 4-klasową szkołę ludową pospolitą z zamiarem powiązania jej z projektowanym 8-klasowym gimnazjum.Jednocześnie ze szkołą gimnazjalną miała zostać otwarta 8-klasowa pensja. Strażyńska podjęła zatem próbę połączenia w jednej placówce obu typów kształcenia dziewcząt: gimnazjalnego i licealnego. Do szkoły przyjmowano wyłącznie chrześcijanki.

W roku szkolnym 1903/04 ruszył kurs przygotowawczy z pięcioma uczennicami. Skok organizacyjny nastąpił w roku szkolnym 1905/06, kiedy doszły do kursu jeszcze trzy niższe klasy gimnazjalne,

33 Sprawozdanie Dyrekcji prywatnego wyższego gimnazjum żeńskiego im. Królowej Jadwigi w Krakowie („Patac Spiski”) za rok szkolny 1905/06, Kraków 1906, s. 27, 32; R. Dutkowa, Żeńskie gimnazja Krakowa w procesie emancypacji kobiet (1896-1918), dz. cyt., s. 32-34; B. Czajecka, „Z domu w szeroki swiat...", dz. cyt., s. 119-120. 
a szkołę zasiliły dziewczęta, które odeszły z pierwszego gimnazjum. Prawa publiczne szkoła otrzymała $\mathrm{w}$ tym samym roku szkolnym w 1905/06, a od roku 1907/08, jako pierwsza w Krakowie, stała się szkołą 8-klasową, w pełni odpowiadającą organizacyjnie i programowo gimnazjom klasycznym męskim. W czerwcu 1908 roku miał miejsce pierwszy egzamin dojrzałości.

Dyrektorem szkoły był początkowo Mikołaj Mazanowski, profesor II Gimnazjum Męskiego im. św. Jacka, a od roku szkolnego 1905/06 do wybuchu wojny Antoni Mazanowski, wcześniej profesor III Gimnazjum Męskiego w Krakowie im. króla Jana Sobieskiego. Siedziba szkoły znajdowała się w budynku przy ul. Franciszkańskiej 1.

W marcu 1914 roku szkoła zmieniła właścicielkę, a zarazem dyrektora. Właścicielką i dyrektorem szkoły została dr filozofii Maria Strehlówna. Ponieważ Strehlówna została wkrótce żoną dr filozofii Józefa Lewickiego, od roku szkolnego 1914/15 szkoła zmieniła nazwę na Prywatne Gimnazjum Żeńskie drów Józefa i Marii Lewickich ${ }^{34}$.

Jako ostatnie z gimnazjów krakowskich założonych przed wybuchem I wojny światowej powstało gimnazjum realne sióstr urszulanek. Powstało ono z przekształcenia 8-klasowej szkoły żeńskiej (ludowej i wydziałowej) na mocy pozwolenia ministerialnego $z$ dnia 22 grudnia 1910 roku $^{35}$. Dokonując przekształcenia szkoły w gimnazjum realne, urszulanki oparły się na rozporządzeniu Ministerstwa Oświaty z sierpnia 1908 roku, dotyczącego tworzenia 8-klasowych gimnazjów realnych i zreformowanych gimnazjów realnych na bazie liceów lub szkół wydziałowych ${ }^{36}$.

\section{Zakończenie}

„Po kilkunastu latach od założenia pierwszej żeńskiej szkoły średniej - stwierdza Renata Dutkowa - koncepcja gimnazjalnego kształcenia dziewcząt zyskała więc powszechne zrozumienie i akceptację

34 R. Dutkowa, Żeńskie gimnazja Krakowa w procesie emancypacji kobiet (18961918), dz. cyt., s. 34-35; B. Czajecka, „Z domu w szeroki świat”, dz. cyt., s. $120-121$.

35 R. Dutkowa, Żeńskie gimnazja Krakowa w procesie emancypacji kobiet (18961918), dz. cyt., s. 35.

36 B. Czajecka, „Z domu w szeroki świat...”, dz. cyt., s. 105-107. 
w określonych kręgach społecznych, stała się wręcz popularna, a żeńskie gimnazja, choć wyłącznie prywatne, wpisały się trwale w schemat szkolnictwa" ${ }^{37}$.

W 1914 roku w Galicji działało dziewięć żeńskich gimnazjów klasycznych, w tym trzy w Krakowie oraz 17 gimnazjów realnych, w tym jedno w Krakowie. Wszystkie te szkoły były placówkami prywatnymi ${ }^{38}$.

Galicja pod względem liczby tego typu zakładów oraz uczęszczających do nich uczennic wyprzedzała znacznie inne kraje koronne, podobnie zresztą jak miało to miejsce w przypadku gimnazjów męskich. W 1908 roku w całej Przedlitawii 59\% uczennic gimnazjów żeńskich stanowiły uczennice szkół galicyjskich, a w roku 1912 - aż $72 \%{ }^{39}$. Jednym z powodów takiego stanu rzeczy było zapewne to, iż Galicji w znacznie większym stopniu niż w innych krajach koronnych klasy średnie, na ogół mniej zamożne, były bardziej zainteresowane zapewnieniem dziewczętom wykształcenia dającego lepsze perspektywy pracy zawodowej ${ }^{40}$.

\section{BIBLIOGRAFIA}

Bilewicz A., Prywatne, średnie, ogólnoksztatcace szkolnictwo żeńskie w Galicji w latach 1867-1914, (Acta Universitatis Wratislaviensis, No 1897. Prace Pedagogiczne CXVI), Wydawnictwo Uniwersytetu Wrocławskiego, Wrocław 1997.

Czajecka B., „Z domu w szeroki świat...”. Droga kobiet do niezależności w zaborze austriackim w latach 1890-1914, Universitas, Kraków 1990.

Dormus K., Kazimiera Bujwidowa 1867-1932. Życie i dziatalność spoteczno-oświatowa, (Biblioteka Krakowska, nr 144), Wydawnictwo i Drukarnia „Secesja”, Kraków 2002.

Dormus K., Poetka i nauczycielka - Marcelina Kulikowska (1872-1910), „Rozprawy z Dziejów Oświaty” 2011, t. 48.

Dutkowa R., Żeńskie gimnazja Krakowa w procesie emancypacji kobiet (18961918), (Studia nad kształtowaniem się inteligencji w Polsce w XIX i XX wieku, t. 1), Instytut Historii UJ, Kraków 1995.

37 R. Dutkowa, Żeńskie gimnazja Krakowa w procesie emancypacji kobiet (18961918), dz. cyt., s. 37.

38 B. Czajecka, „Z domu w szeroki świat...”, dz. cyt., s. 105-107.

39 R. Dutkowa, Żeńskie gimnazja Krakowa w procesie emancypacji kobiet (18961918), dz. cyt., s. 38.

40 Tamże, s. 17. 
Dyskusja o szkotach średnich w tegorocznej sesji sejmowej, „Muzeum” 1905.

Hulewicz J., Sprawa wyższego wyksztatcenia kobiet w Polsce w wieku XIX, Polska Akademia Umiejętności, Kraków 1939.

Hulewicz J., Udziat Galicji w walce o szkole polska 1899-1914, Komitet Obchodu 25-lecia Walki o Szkołę Polską, Warszawa 1934.

Męczkowska T., Szkoty mieszane. Koedukacja, Wydawnictwo M. Arcta, Warszawa 1920.

Najdus W., Szkice z historii Galicji, t. 2: Galicja w latach 1905-07, Książka i Wiedza, Warszawa 1960.

Sempołowska S., Niedola mtodzieży w szkole galicyjskiej. Kilka stów o narodowej szkole w Galicji, Kraków 1906.

Sprawa gimnazjum żenskiego, Biblioteka Jagiellońska, rkps 7388 II.

Sprawozdanie Dyrekcji prywatnego wyższego gimnazjum żenskiego im. Królowej Jadwigi w Krakowie („Patac Spiski”) za rok szkolny 1905/06, Kraków 1906.

Sprawozdanie Dyrektora prywatnej średniej szkoty żenskiej z programem gimnazjalnym w Krakowie za rok szkolny 1902/03, Kraków 1903.

Sprawozdanie Dyrektora prywatnej średniej szkoty żenskiej z programem gimnazjalnym w Krakowie za rok szkolny 1905/06, Kraków 1906.

Sprawozdanie Towarzystwa szkoty gimnazjalnej żeńskiej za rokszk. 1899/1900, Kraków 1900.

Sprawozdanie Towarzystwa szkoty gimnazjalnej żeńskiej za rok szk. 1900/01, Kraków 1901.

Sprawozdanie Towarzystwa szkoty gimnazjalnej żeńskiej za czas od kwietnia 1905 r. do 21 grudnia 1905 r., Kraków 1905.

Stinia M., Rola spoteczeństwa galicyjskiego jako organizatora średniego szkolnictwa prywatnego w okresie autonomii, w: $Z$ dziejów polskiej kultury i oświaty od średniowiecza do początków XX wieku, red. K. Jakubiak, T. Maliszewski, (Szkoła, Państwo, Społeczeństwo, t. 1), Oficyna Wydawnicza Impuls, Kraków 2010.

W sprawie prywatnej średniej szkoty żenskiej w Krakowie. Odpowiedż Zarzqdu Towarzystwa szkoty gimnazjalnej ̇̇enskiej na dwa artykut „Czasu”, Kraków 1905.

Zachara J., Historia pierwszego na ziemiach Polski Gimnazjum Żeńskiego im. E. Plater w Krakowie. (Przemówienie na uroczystości czterdziestolecia), Kraków 1937.

\section{ADRES DO KORESPONDENCJI}

Dr hab. Katarzyna Dormus, prof. UP

Uniwersytet Pedagogiczny w Krakowie

Wydział Pedagogiczny, Instytut Pedagogiki Przedszkolnej i Szkolnej

kdormus@op.pl 